\title{
Edible insects: Future of Human food - A Review
}

\author{
Partha Pal ${ }^{1, *}$, Spandita Roy ${ }^{2}$ \\ ${ }^{1}$ Department of Zoology, Scottish Church College, 1 \& 3 Urquhart Square, Kolkata - 700006, India \\ ${ }^{2}$ Presidency University, 86/1, College Street, Kolkata - 700073, India \\ *E-mail address: parthapal_iicb@yahoo.co.in
}

\begin{abstract}
The practice of eating insects is known as entomophagy. Many animals, such as spiders, lizards and birds, are entomophagous, as are many insects. People throughout the world have been eating insects as a regular part of their diets for millennia. As people in rural areas suffer from under nutrition, especially protein-energy malnutrition (PEM) in Africa, Latin America and Asia, alternative nutritional food sources are needed. From ants to beetle larvae - eaten by tribes in Africa and Australia as part of their subsistence diets - to the popular, crispy-fried locusts and beetles enjoyed in Thailand, it is estimated that insect-eating is practised regularly by at least 2 billion people worldwide. More than 1900 insect species have been documented in literature as edible, most of them in tropical countries. The most commonly eaten insect groups are beetles, caterpillars, bees, wasps, ants, grasshoppers, locusts, crickets, cicadas, leaf and plant hoppers, scale insects and true bugs, termites, dragonflies and flies. The purpose of the present review is to determine the status of present research in the context of the potentiality of insects as alternative food source to cope up with the emerging problem of global food crisis.
\end{abstract}

Keywords: Entomophagy; Edible-Insects; Nutrients; Conservation; Food Crisis

\section{INTRODUCTION}

Entomophagy is the consumption of insects as food'. The term "entomophagy" derives from the Greek term "entomos" meaning insects; and "phagein" means "to eat"; Combining both term mean 'insect eating'. Entomophagy is practised in many countries around the world but predominantly in parts of Asia, Africa and Latin America. Insects supplement the diets of approximately 2 billion people and have always been a part of human diets.

Mainly tropical and sub - tropical countries such as, Zimbabwe, Mexico, Thailand and many others have well-known insect-eating regions; also in more temperate regions such as Japan and some parts of China insects are being eaten. Here, insects are renowned for their nutritional and economical benefits.

Many insect species are edible, including ants, grasshoppers, bees, wasps, crickets etc. Approximately 1400 insect species of the world are known to be edible (van Huis, 2003). In Thailand, where edible insects are very popular, 164 insect species are collected en mass and sold in for instance markets and supermarkets in Bangkok (Yhoung-Aree and Viwatpanich, 2005). 
In Southern Africa the 'mopane worm' (a caterpillar) is the most important edible insect and is being collected and sold in huge quantities as well (Kozanayi and Frost, 2002). Trade in edible insects is economically important.

\section{MODERN DAY ENTOMOPHAGY}

The Italian entomologist and naturalist Ulysse Aldovandi, born in 1522, is considered the founder of the modern-day study of insects. Aldovandi's De Animalibus Insectis Libri Septem, published in 1602, is rich in references and concepts derived from his studies as well as original observations. Aldovandi, a specialist in cicadas, suggested that insects were important food items in ancient Far Eastern civilizations, namely China.

In the United States, swarms of Rocky Mountain locusts (Melanoplus spretus) regularly swept across the western half of the country (as far north as Canada) in the nineteenth century, devastating farming communities (Lockwood, 2004). One famed sighting estimated that the locusts spanned 198000 square miles. This swarm weighed an estimated 27.5 million tonnes and consisted of some 12.5 trillion insects, which according to The Guinness Book of Records was the greatest concentration of animals ever recorded.

\section{MAJOR GROUPS OF EDIBLE INSECTS}

Globally, the most common insects consumed are beetles (Coleoptera), beside this, other groups of edible insects are 1) Lepidoptera-caterpillar 2) Hymenoptera-bee, wasp 3) Orthoptera-locust,cricket,grasshopper 4) Hemiptera-true bugs, cicadas, leafhoppers, plant hoppers, scale insects 5) Isoptera-termites 6) Odonata-dragonfly 7) Diptera-flies

\section{WHY ARE INSECTS NOT EATEN IN WESTERN COUNTRIES?}

The Fertile Crescent, a region comprising fertile lands in western Asia and the Nile Valley and Nile Delta in northeast Africa is believed to be one of the regions in which agriculture originated. From there, food production (i.e. plant and animal domestication) spread swiftly throughout Europe (Diamond, 2005). The most valuable wild animal species to be domesticated were large terrestrial mammalian herbivores and omnivores. There are 14 such domesticated mammals worldwide.

These animals not only yielded considerable amounts of meat (making them the main providers of animal-based foods), but also warmth, milk products, leather, wool, plough traction and means of transport. It is thought that it was because of the utility of these animals that the use of insects - besides honeybees, s People in most Western countries views entomophagy with feelings of disgust (Rozin and Fallon, 1987). It is safe to say that most are reluctant to even consider eating insects and, moreover, that they perceive the practice to be associated with primitive behaviour (Vane-Wright, 1991; Ramos Elorduy, 1997; Tommaseo Ponzetta and Paoletti, 1997).silkworms and scale insects - failed to gain much traction in the West. Insects simply could not offer the same benefits.

Culture, under the influence of environment, history, community structure, human endeavour, mobility and politico- economic systems, defines the rules on what is edible and what is not 
(Mela, 1999). In short, the acceptance or rejection of entomophagy is a question of culture (Mignon, 2002).

\section{WHY ARE INSECTS CONSUMED IN THE TROPICS MORE THAN IN TEMPERATE AREAS OF THE WORLD?}

It is generally assumed that the practice of eating insects takes place exclusively in tropical countries. This is not entirely true, as insects are also consumed in countries partially or fully in temperate zones, such as China (Feng and Chen, 2003), Japan (Mitsuhashi, 2005) and Mexico (Ramos Elorduy, 1997).

Insects tend to be larger in the tropics, which facilitates harvesting. Like humans, insects require oxygen and produce carbon dioxide as a waste product. Instead of lungs, however, insects use a series of tubes called a tracheal system. The gases are mainly exchanged throughout the body by diffusion, which happens faster at higher temperatures, allowing for the production of bigger insects in warmer climates (Kirkpatrick, 1957). As fossil evidence shows, insects had much larger body sizes during the late Palaeozoic period (Shear and Kukalová-Peck, 1990), some as large as 1 metre, because of higher atmospheric temperatures. In the tropics, insects often congregate in significant numbers, so large quantities can be collected during a single harvest. Locust swarms settle for the night, making harvesting very easy in the evening and early morning. Caterpillars in forests congregate en masse by nature. Some insects also congregate in temperate regions, such as the Mormon cricket (Anabrus simplex) and the oak caterpillar (Thaumetopoea processionea). Native Americans likely ate the Mormon cricket (Madsen and Kirkman, 1988). A variety of edible insect species can be found year-round in the tropics. In temperature zones, insects hibernate to survive cold winters. During this period, no active insect species can be found, and their development comes to a standstill. Palm weevils, for example, are found in palms that have fallen (e.g. often in typhoons in Asia) or that have been felled deliberately to trigger beetles to lay eggs (Choo et al., 2009). Bamboo caterpillars can be found in stems of bamboo, dung beetles under dung heaps, soldier termites in termite mounds, and so on.

\section{WHERE AND WHEN ARE INSECTS EATEN?}

The frequency of insect consumption around the world is poorly documented. The few examples found in literature are from Africa, Asia and Latin America.

Insects can be found in abundance throughout the African continent and when staples are scarce they become important sources of food. During the rainy season - when hunting game or fish can be problematic - insects play an important role in food security.

Between 150 and 200 species of edible insect are consumed in Southeast Asia. Red palm weevils (Rhynchophorus ferrugineus) from the Sago palm (Metroxylon sagu) are especially popular across the continent and are a highly prized delicacy in many regions (Johnson, 2010). Some insects are available year-round (dragonfly larvae, diving beetles, giant water bugs), including many aquatic species, while others are only available on a seasonal basis (grasshoppers, cicadas, weaver ants).

In Mexico, indigenous people possess a deep knowledge of the plant and animal species that traditionally make up their diets, including the life cycles of insects (Ramos-Elorduy, 1997). Insects have been "calendarized" by species, meaning that they are believed to operate 
in harmony with natural phenomena such as plant life cycles, moon cycles, rainy seasons and thunder. It is widely known among indigenous people, for instance, that escamoles (larvae of the ants of the Liometopum genus) are ready to harvest when the jarilla plant (Senecio salignus) is flowering.

\section{NUTRITIVE VALUE OF INSECTS}

Insects have been well-recognized worldwide as nutritious food, since insects provide Proteins (amino acids such as methionine, cysteine, lysine, and threonine), Carbohydrate, Fats, Some minerals (calcium, iron,zinc, phosphorous), Some essential vitamins -vitamin A, B complex, C (Capinera, 2004; Johnson, 2010; Xiaoming et al., 2010).

Caterpillars contain proteins to the extent of $50-60 \mathrm{~g} / 100 \mathrm{~g}$ dry weight, the palm weevil grubs contain 23-36g, Orthoptera contain 41-91g, ants contain 7-25g and termites contain 35$65 \mathrm{~g} / 100 \mathrm{~g}$ (Bukkens, 1997; Ramos-Elorduy, 2005). This quantity is more than in ground beef (27.4g) or broiled cod fish (28.5g) (Banjo et al., 2006; Okaraonye and Ikewuchi, 2008).

Maximum contents of $100 \mathrm{~g}$ amino acids $/ 100 \mathrm{~g}$ dry weight of silkworms' pupae followed by the bamboo caterpillar Omphisa fuscidentalis Hmps. (Lepidoptera: Crambidae) (77.5g) and the house cricket $(68.7 \mathrm{~g}$ ) have been reported (Yhoung-aree, 2010). Caterpillars, grubs of palm weevils Rhynchophorus spp. (Coleoptera: Curculionidae)) and termites are rich in fat (Bukkens, 1997). Maximum contents of calcium of 61.3, 72.4 and 76g/100g dry weight have been recorded, respectively, in dung beetle (Oryctes sp. (Coleoptera: Scarabaeidae)) grubs (Banjo et al., 2006), palm weevil grubs (Onzikou et al., 2010) and adult house crickets (Vogel, 2010). Maximum contents of iron of 27-29 and 35.5g/100g dry weight have been found in termites and caterpillars, respectively (Banjo et al., 2006). Similarly, maximum contents of phosphorus of 226-238g/100g are present in grasshoppers and the giant water bug Lethocerus indicus (Hemiptera: Belostomatidae; Feng et al., 2000). A high content of magnesium $(7.54-8.21 \mathrm{~g} / 100 \mathrm{~g})$ has been found in grasshoppers and weevils (Banjo et al., 2006). Eggs, larvae and pupae of honeybees have a high amount of vitamins A, B2 and C to the extent of $12.44 \mathrm{mg} / 100 \mathrm{~g}, 3.24 \mathrm{mg} / 100 \mathrm{~g}$ and $10.25 \mathrm{mg} / 100 \mathrm{~g}$, respectively (Bukkens, 1997). Calories obtainable from insects run as high as $776.9 \mathrm{kcal} / 100 \mathrm{~g}$ of insects, often exceeding those from soybean, maize and beef (Ramos-Elorduy, 2005).

In a recent study in Kenya, wheat buns enriched $(5 \%$ mix $)$ with the termite Macrotermes subhyalinus Rambur (Isoptera: Termitidae) were better than ordinary breads for some attributes (e.g. size, colour, texture, aroma) and consumers' preference. Further, Kinyuru et al. (2009) found higher contents of riboflavin $(0.17$ versus $0.26 \mathrm{mg})$, niacin $(0.90$ versus $1.11 \mathrm{mg})$, folic acid $(0.30$ versus $0.33 \mathrm{mg})$, calcium (10 versus $10.83 \mathrm{mg})$, iron $(1.20$ versus $1.80 \mathrm{mg})$ and zinc $(2.78$ versus $3.23 \mathrm{mg})$ than in ordinary bread. The oil extracted from $R$. phoenicis grubs contains a high level of unsaturated components and exhibits good physiological properties due to which it is used as edible oil (Okaraonye and Ikewuchi, 2008; Onzikou et al., 2010). In the case of silkworm caterpillars, eating them can be sufficient for daily requirements of copper, zinc, iron, thiamine and riboflavin, and the deficiency of riboflavin can be fulfilled by eating those insects containing this amino acid (Gordon, 1998). Protein production from insects is also ecologically sustainable and consumes fewer resources than animal protein (Gordon, 1998). 


\section{RECENT DEVELOPMENTS IN INSECTS COLLECTION}

The grubs of $R$. phoenicis and the coconut rhinoceros beetles (Scarabaeidae) belonging to group Coleoptera are a common food in the Democratic Republic of Congo (DRC) (Onyeike et al., 2005; Onzikou et al., 2010) and Nigeria (Ekpo and Onigbinde, 2005). Dung beetles including Heliocopris bucephalus (Scarabaeidae) are collected generally in the morning by digging them out from cattle dung, placed into a container filled with water to soak for $12 \mathrm{~h}$ or until no more food remains in their intestines before they can be cooked (Hanboonsong, 2010).

Lake flies, Chaoborus spp. (Chaoboridae) belonging to group Diptera rise like clouds from Lake Victoria in East Africa. Natives sweep them off from bushes and rocks and collect them by whirling baskets. Cake is prepared by grinding the flies, which is then sun-dried (van Huis, 2003). Collecting water bugs around lights at night near water sources is an age-old practice in Mexico where bug eggs are well known for their taste. Two rice bugs, Leptocorisa oratorius (Coreidae) and Nezara viridula L. (Pentatomidae), are relished by farmers in Borneo. They mash the bugs with chillies and salt and cook them in hollow bamboo stems. The dish is served as a condiment (Chung, 2010). In China, the giant water bug L. indicus is roasted and eaten whole or ground into a paste with chillies before eating (Feng et al., 2000). Larvae and pupae (and rarely adults) of honeybees and social wasps are roasted/grilled over a fire and cooked with wasps or honeybees in Japan, China and Java (Edwards, 1998; Feng et al., 2010). Larvae and pupae of the social honeybee Apis cerana, the giant honeybee $A$. dorsata F., the dwarf honeybee A. florea and the stingless bee (Apidae) are boiled with porridge or rice, stir-fried or drunk together with honey. Sometimes the brood together with the hive is squeezed to extract liquid which is then boiled (Adalla and Cervancia, 2010; Chung, 2010).

In mountainous areas in Japan, pupae of the common wasp Vespula flavipes L., the Asian giant hornet Vespa mandarinia Smith, Vespa spp. and Ropalidia spp. (Vespidae) are boiled with soybean sauce or fried with salt while larvae are boiled to a hard consistency with soybean sauce, sugar and sake'. The cooked larvae are then mixed with rice (Chung, 2010; Nonaka, 2010).

Large colonies of termites are found in arid and humid areas of Central Africa and Australia. Eating of the queen and the reproductive forms is common globally, whereas soldiers are preferred in Venezuela (Paoletti et al., 2003). The most popular and easy way used in the tropics is to collect them during the evening hours by placing a basin of water right under the light source. As light is reflected on the water, termites are attracted and trapped on the water surface (Chung, 2010).

Caterpillars of moths and butterflies have been popular dishes in many parts of the world, whereas pupae of the eri silkworm Samia ricini Donovan, the Chinese oak silk moth Antheraea pernyi Guerin- Meneville and the mulberry silkworm Bombyx mori L. (Saturniidae) are consumed by locals in many Asian countries (Zhou and Han, 2006; Sirimungkar- akat et al., 2010; Sarmah, 2011). Eating of the bamboo caterpillar $O$. fuscidentalis and the cassia butterfly Catopsila pomona (Pieridae), both rich in proteins $(25 \mathrm{mg} / 100 \mathrm{~g}$ dry weight), has been reported in Southeast Asia (Yhoung-aree et al., 1997). Native women in the Kalahari region of South Africa squeeze out the intestines of caterpillars, and roast them in hot ash and sand. They store sun-dried caterpillars in bags for consumption whenever the need arises. For this purpose, dried caterpillars are often pounded into powder and mixed together with stewed watermelon (Nonaka, 1996). 
Dragonflies including the larger green emperor dragonfly Anax guttatus Burm (Aeshnidae) and the red-veined dropwing Trithemis arteriosa Burm. (Libellulidae) are collected in paddy fieldsss in the DRC (Malaisse, 1997), the Philippines, north and northeast Thailand (Pemberton, 1995), and China (Feng et al., 2001). Nymphs are often stir-fried or boiled before eating.

Grasshoppers, crickets and locusts are eaten by Africans as delicacies (Mbata, 1995). Grasshoppers (Acrididae) including Acanthacris ruficornis, A. nigrovariegata Bolivar, Locusta migratoria migratoriodis (L.), and other jumping insects are collected in the early morning and evening when insects gather and are inactive. Villagers use brooms made from leaves or branches of local trees to chase grasshoppers from trees and huts (Mbata, 1995; Nonaka, 1996; Roulon- Doko, 1998).Early morning when crickets rest on grasses or low tree branches is the ideal time for collection. In Thailand, a small hole is made in the ground near the nest and water is poured into it. The crickets come out to the surface and are easily collected by hand (Hanboonsong, 2010). Farmers stir-fry the insects without oil (Chung, 2010).

\section{PRACTICE OF EATING INSECTS IN INDIA}

In India, eating of honey bee comb with the brood (eggs and larvae) is common practice in certain areas. Interestingly, some Indian tribes eat the pupae of silkworm. In a 2013 report, FAO (Food and agriculture Organisation) presents insects as a viable replacement for meat in the event of a food shortage over the next century because of their high nutritional value.

\section{EDIBLE INSECTS ECOLOGY}

The edible insect resource is primarily a category of non-wood forest products (NWFPs) collected from natural resources (Boulidam, 2010). Edible insects inhabit a large variety of habitats, such as aquatic ecosystems, forests and agricultural fields. On a smaller scale, edible insects may feed on the foliage of vegetation (e.g. caterpillars) or roots (e.g. witchetty grubs), live on the branches and trunks of trees (e.g. cicadas) or thrive in soils (e.g. dung beetles). Insect ecology can be defined as the interaction of individual insects and insect communities with the surrounding environment. This involves processes such as nutrient cycling, pollination and migration, as well as population dynamics and climate change. Some species that have long been considered valuable for their products - such as honeybees, silkworms and cochineal insects - are well known, while knowledge of many others remains scarce.

\section{1. Collecting from the wild: potential threats and solutions}

Insects provide essential ecosystem services such as pollination, composting, wildfire protection and pest control (Losey and Vaughan, 2006). Edible insects, such as honeybees, dung beetles and weaver ants, eaten extensively in the tropics, perform many of these ecological services. A number of anthropogenic factors impose threats on edible insect populations. Collection itself can result in direct competition with other predators, undermining population viability (Choo, 2008). Many edible insect species are predators themselves or decomposers. A reduction in their numbers may have adverse effects on populations of other insect species and affect ecosystem functions. 
Overexploitation is another serious challenge to both the current and future practice of entomophagy (Morris, 2004; Schabel, 2006), particularly if the number of collected individuals (mature and immature) exceeds regeneration capacity (Cerritos, 2009). In addition, the stability and regeneration of edible insect populations is threatened if collection practices become less selective (Latham, 2003; Illgner and Nel, 2000; Ramos Elorduy, 2006). This happens, for example, when mature insects are collected before their first mating or before they lay eggs (Cerritos, 2009). Finally, like many other natural resources, damage to habitat, such as deforestation, forest degradation and pollution (e.g. through insecticides), has placed further stress on edible insect populations (Morris, 2004; Ramos Elorduy, 2006; Schabel, 2006). Host trees are often cut down to increase and facilitate the collection of insects.

\section{2. Conservation and management of edible insect resources}

Scientists generally speak about biodiversity on three levels: ecosystem, species and genetic. Biodiversity can make significant contributions to food security and improved nutrition (Toledo and Burlingame, 2006). In view of the ecological services insects provide, deemed vital to human life, the conservation of insects and the habitats they occupy has recently received more attention (DeFoliart, 2005; Samways, 2007). The promotion of "flagship species" is used to stimulate public interest in conservation efforts (Simberloff, 1998). Conservation biologists identify "umbrella species" as representative species whose protection is believed to indirectly benefit a large number of naturally co-occurring species and their habitats (Roberge and Angelstam, 2004). While these species tend to be large, emblematic mammals, such as giant pandas and tigers, the possibility of edible insect species as flagship species and/or umbrella species protecting other natural resources deserves attention, not least because of the valuable role they have in the provision of essential ecosystem services (Yen, 2009; DeFoliart, 2005). Foresters and forest industries have long considered caterpillars as pests because they feed on fresh leaves (tree foliage) and are therefore perceived to be harmful to tree populations. In reality, however, trees respond to such browsing by producing more foliage. N'Gasse et al. (2004) observed that leaf consumption by caterpillars had only a limited impact on trees. In fact, the collection of caterpillars in the forest could be considered a method of biocontrol, so long as trees are not cut during the caterpillar harvest (Vantomme, Göhler and N'Deckere-Ziangba, 2004).

\section{DISCUSSION AND CONCLUSION}

Awareness of entomophagy among consumers and insect-rearing entrepreneurs is necessary (Nonaka, 2005). In some instances, consumers are willing to pay a premium for the safety of street foods including insect preparations if prepared, stored and sold in a hygienic condition (Akinbode et al., 2011). Such an attempt was made in 2010 in the USA by organizing an international seminar on 'The potential of edible insects' at Linvile, Alabama, USA, by the Southern Institute for Appropriate Technology. Similarly, a workshop at ChiangMai in Thailand on 'Edible insects' co-organized by the FAO in 2008 was a great success. After all, entomophagy can be revalidated by worldwide campaigns that are to be launched in those countries that are facing acute food shortage. A multi-faceted and linked global strategy is, therefore, needed to ensure sustainable and equitable food security (FAO, 2010).

In the present review it is concluded that more research should be targeted on extensive surveys of insects, search of literature, research on nutritional value of unknown species as 
well as socio-economic aspects (including acceptance of these foods by consumers) which will open up new vistas for food security in the present era of scarcity of edible food sources in the world. This novel approach of entomophagy can play an inter-disciplinary role associated with forestry, traditional medicine, agriculture and animal husbandry to combat the present scenario of global food crisis.

\section{Acknowledgement}

The authors convey their gratitude to Dr. Sumana Saha Associate Professor P.G Department of Zoology Darjeeling Government College for providing the necessary literatures, planning for doing this review paper.

\section{References}

[1] Adalla C.B., Cervancia C.R., Proceedings of a Workshop on Asia-Pacific Resources and Their Potential for Development In Forest Insects as Food: Humans Bite Back., 1921 February 2008, FAO (2010) 151-160.

[2] Akinbode S.O., Dipeolu A.O., Okuneye P.A., Journal of Agricultural and Food Information 12 (2011) 154-166.

[3] Banjo A.D., Lawal O.A., Songonuga E.A., African Journal of Biotechnology 5 (2006a) 298-301.

[4] Banjo A. D., Lawal O.A., Adeyemi A.J., Journal of Applied Sciences Research 2 (2006b) $837-843$

[5] Boulidam S., Forest insects as food: humans bite back, proceedings of a workshop on Asia-Pacific resources and their potential for development. Bangkok, Thailand, FAO Regional Office for Asia and the Pacific (2010) 131-140.

[6] Bukkens S.G.F., Ecology of Food and Nutrition 36 (1997) 287-319.

[7] Capinera J.L., Encyclopedia of Entomology 1(3) (2004) 258.

[8] Cerritos R., CAB Reviews: Perspectives in Agriculture, Veterinary Science, Nutrition and Natural Resources 4(27) (2009) 1-10.

[9] Choo J., Terrestrial Arthropod Reviews 1(2008) 81-93.

[10] Choo J., Zent E.L., Simpson B.B., Journal of Ethnobiology 29(1) (2009) 113-128.

[11] Chung A.Y.C. Proceedings of a Workshop on Asia-Pacific Resources and Their Potential for Development, 19-21 February 2008, FAO, (2010) 141-150.

[12] Chung A.Y.C., Chey V.K., Unchi S., Tinge K.S. Won A., Malaysian Naturalist 55 (2001) 24-29.

[13] DeFoliart G.R., Ecological implications of minilivestock: potential of insects, rodents, frogs and snails, (2005) 123-140.

[14] Durst P.B., Shono K., Proceedings of a workshop on Asia-Pacific resources and their potential for development Bangkok, FAO Regional Office for Asia and the Pacific (2010) 1-4.

[15] Edwards J.S., Honey Bee Science 19 (1998) 149-154. 
[16] Ekpo K.E., Onigbinde A.O., Pakistan Journal of Nutrition 4 (2005) 287-290.

[17] FAO., Contribution des insects de la foret a la securite alimentaire. L'exemple des chenilles d'afrique centrale (2004).

[18] FAO., The State of Food Insecurity in the World (2009) Economic and Social Development Department, Food \& Agriculture Organization, Rome (2010).

[19] $\mathrm{FaO} / W u r .$, Expert consultation meeting: assessing the potential of insects as food and feed in assuring food security, Rome (2012).

[20] FAO., Overview on aquaculture and fish farm feeds (including some insect species) of World Fisheries and Aquaculture (2013).

[21] Feng Y., Chen X., Wang S., Ye S., Chen Y., Forest Research 13 (2000) 608-612.

[22] Feng Y., Chen X., Wang S., Ye S., Chen Y., Forest Research 14 (2001) 421-424.

[23] Feng Y., Chen X., Forest Science and Technology 44(4) (2003) 19-20.

[24] Feng Y., Chen X., Sun L., Che Z.Y., Proceedings of a Workshop on Asia-Pacific Resources and Their Potential for Development, 19-21 February 2008 (2010) 93-98.

[25] Gordon D.G., Ten Speed Press, Berkeley, CA (1998) 102.

[26] Hanboonsong Y., Proceedings of a Workshop on Asia - Pacific Resources and Their Potential for Development, 19-21 February 2008 (2010) 173-182.

[27] International Feed Industry Federation. Annual report 2010 (2011), available at www.ifif.org/uploadImage/2012/1/4/f41c7f95817b4c99782 bef7abe8082dd1325696464.pdf.

[28] Johnson D.V., Proceedings of a workshop on resources and their potential for development, pp.. Bangkok, FAO Regional Office for Asia and the Pacific (2010) 5-22.

[29] Kinyuru J.N., Kenji G.M., Njoroge M.S., African Journal of Food, Agriculture, Nutrition and Development 9 (2009) 1739-1750.

[30] Latham P., Canterbury Mystole Publications (2003).

[31] Lockwood J.A., New York, USA, Basic Books (2004).

[32] Losey J.E., Vaughan M., Bioscience 56(4) (2006) 311-323.

[33] Madsen D.B., American Antiquity 53(3) (1988) 593-604.

[34] Mbata K.J., The Food Insects Newsletter 8 (1995) 5-7.

[35] Mela D.J., Proceedings of the Nutrition Society 58 (1999) 513-521.

[36] Mignon J., Tropicultura 20(3) (2002) 151-155.

[37] Mitsuhashi J., Ecological implications of minilivestock; role of rodents, frogs, snails, and insects for sustainable development (2005) 251-262.

[38] Morris B., Oxford UK Berg (2004).

[39] N'Gasse G., Produits Forestiers Non Ligneux: Document de Travail 1. Rome FAO (2004).

[40] Nonaka K., African Study Monographs (Supplement) 22 (1996) 29-46. 
[41] Nonaka K., Proceedings of a Workshop on Asia - Pacific Resources and Their Potential for Development, 19-21 February 2008, FAO (2010).

[42] Okaraonye C.C., Ikewuchi J.C., Journal of Biological Science 8 (2008) 122-125.

[43] Onyeike E.N., Ayalogu E.O. Okaraonye C.C., Journal of the Science of Food and Agriculture 85 (2005) 1822-1828.

[44] Paoletti M.G., Buscardo E., VanderjagtD.J., Pastuszyn A., Pizzoferrato L., Hunag V., Chung T., Millson M., Cerda H. and Glew R. H., Ecology of Food and Nutrition 42 (2003) 173-187.

[45] Pemberton R.W., American Entomologist 4 (1995) 97-99.

[46] Ramos-Elorduy J., Ecology of Food and Nutrition 36 (1997) 347-366.

[47] Ramos-Elorduy J., Potential of Insects, Rodents, Frogs and Snails for Sustainable Development (2005) 263-291.

[48] Ramos-Elorduy J., Pino J.M., Entomología Mexicana 1 (2006) 524-533.

[49] Roberge J.M., Angelstam A.P., Conservation Biology 18(1) (2004) 76-85.

[50] Rozin P., Fallon A.E., Psychological Review 94(1) (1987) 23-41

[51] Samways M.J., Ann Rev Entomol 52 (2007) 465-487.

[52] Schabel H., Forest entomology in East Africa: forest insects of Tanzania (2006) 247-294.

[53] Sirimungkarakat S., Saksirirat W., Nopparat T., Natongkham A., Proceedings of a Workshop on Asia-Pacific Resources and Their Poten-tial for Development, 19-21 February 2008 (2010) 189-200.

[54] Toledo A., Burlingame B., Journal of Food Composition and Analysis 19 (2006) 477-483.

[55] Tommaseo-Ponzetta M., Paoletti M.G., Ecology of Food and Nutrition 36 (1997) 321-346.

[56] van-Huis A., Insects in oral literature and traditions (2003) 367-382.

[57] Vane-Wright R.I., Bulletin of Entomological Research 81(1991) 1-4.

[58] Vantomme P., Göhler D., N’Deckere-Ziangba F., Odi Wildlife Policy Briefing 3 (2004).

[59] Yen A.L., Journal of Insect Conservation 13 (2009) 667-670.

[60] Yhoung-aree J., Puwastien P.P., Attig G.A., Ecology of Food and Nutrition 36 (1997) 133-149.

[61] Zhou J.X., Han D., Food and Chemical Toxicology 44 (2006) 1123-1130. 
Website address:

1) http://qz.com/186677/indias-solution-to-its-coming-famine -get-people-to-eat-insects/

2) www.un.org/apps/news/story.asp?NewsID $=44886$

3) news.nationalgeographic.com/news/2013/13/130514-edible-insects-entomophagyscience-food-bugs-beetles/

4) www.fao.org/fishery/topic/13538/en

5) www.fao.org/docrep/007/j3463f/j3463f00.htm 